\title{
4
}

\section{EL PROCESO DE CONFIGURACIÓN DE LAS POLÍTICAS PÚBLICAS DE GESTIÓN DE RESIDUOS EN LA PLATA ENTRE 2002 Y 2016}

\author{
Mariana Saidón (•) \\ Universidad de Buenos Aires / CONICET \\ España Verrastro $(\cdot \cdot)$ \\ Universidad Nacional de San Martín
}

\section{RESUMEN}

Este trabajo examina cómo se configura la nueva agenda de gestión de residuos en el caso de la ciudad de La Plata, Provincia de Buenos Aires. Analiza en qué aspectos esta nueva agenda logró implementarse y en cuáles no, ahondando en los motivos. Se desarrolla un análisis de caso que utiliza una metodología de tipo cualitativa, revisión documental y bibliográfica. La inscripción de la Gestión Integral de Residuos en la agenda política se explica por la nueva normativa, por patrones de acción colectiva específicos y su vinculación con la justicia; así como por nuevos espacios que generó el gobierno local. Sin embargo, si bien la reforma implementada da cuenta de un inminente cierre del relleno sanitario de Ensenada, no resulta claro que se de paso al modelo previsto en la normativa de manera extendida y sistemática en un marco en el que diversos actores se comportan estratégicamente para resistir el cambio y la gestión resulta compleja.

\section{PALABRAS CLAVE:}

Gestión Integral de Residuos, planta de tratamiento, La Plata, agenda, rellenos sanitarios.

\footnotetext{
(•) E-mail: msaidon@yahoo.com

(••) E-mail: everrastro2@gmail.com
}

\section{ABSTRACT}

This paper examines how the new waste management is set in public agenda in the case of the city of La Plata, Provincia de Buenos Aires. We analyze in what extent this new agenda is implemented, delving into the reasons. A case analysis is developed using qualitative methodology, a documental and bibiliographic review. The inscription of Integrated Waste Management in the public agenda is explained by new laws; specific action collective patrons and their link with justice; as by new spaces that local government generated. However, while implemented reform shows an imminent closing of the landfill in Ensenada, it is no clear that the model that regulations establish would be adopted in a comprehensive and systematically way, in a context in which different actors behave strategically to resist change process and management is complex.

\section{KEY WORDS :}

Integral Waste Management, material recycling plant, La Plata, public agenda, landfills.

RECEPCIÓN: 13/06/16

ACEPTACIÓN FINAL: 10/02/17 